\title{
Analysis of the Planning Process at the Health Center Level at the Poso Regency Health Office
}

\author{
Heindra Baithard Rantung ${ }^{1}$, Darmawansyah ${ }^{1}$, Muhammad Asdar ${ }^{1}$ \\ ${ }^{1}$ Faculty of Public Health, Hasanuddin University, Indonesia
}

\begin{abstract}
One of the activities required by every puskesmas (Community Health Center) in overcoming the problems faced in each area is planning at the puskesmas level. To accommodate the need to increase the ability and coverage of health services in an integrated and integrated manner with the problems that exist in the work environment of the Puskesmas. The purpose of this study was to analyze the planning process at the Puskesmas level at the Poso District Health Office. This type of research is qualitative and the unit of analysis from the implementation of this research is carried out on 2 (two) Puskesmas in the Poso District Health Office. Meanwhile, the research informants were employees/staff of the related puskesmas and the key informant was the Head of the Poso District Health Office as a triangulation check for the validity of the data. The results of the research based on the preparation stage, a planning team was formed by the Head of the Puskesmas, in the situation analysis stage the problem analysis process was carried out through Encuesta Mawas Diri (SMD), the problem formulation stage using the USG method (Uraaatanga metoaaa) problems, the last stage was the preparation of the RUK (Proposed Activity Plan) which are prepared at the puskesmas still refer to the applicable government policies. Suggestions in this study are expected that the puskesmas in the Poso District Health Office can arrange their annual activity plans optimally, while still fostering community participation in improving community health status.
\end{abstract}

Keywords: Preparation, Situation Analysis, Problem Formulation, Preparation of RUK

Received: June 7, 2021

Revised: July 3, 2021

Accepted: July 16, 2021

\section{Introduction}

Community Health Centers, hereinafter referred to as Puskesmas, are health service facilities that carry out public health efforts and first-level individual health efforts, with prioritizing promotive and preventive efforts, to achieve the highest public health status in their working areas (Permenkes, 2014).

The Puskesmas as one of the first-level health service facilities (FKTP) has specificity compared to other FKTPs (Principal Clinic, Individual Practice Places, and others). Several things are the specialty of the Puskesmas, among others: carrying out community efforts (UKM), implementing individual health efforts (UKP) and having a regional concept. With this specificity, of course, good management is needed in managing all the efforts made, all the potential and resources, which will be different from other FKTPs (DINKES, K. p. 2018).

Planning is the process of anticipating future events and determining strategies to achieve organizational objectives in the future (Supriyanto \& Damayanti, 2007). Planning at the puskesmas level is one of the activities required by every puskesmas in overcoming the problems faced in each region. The planning at the puskesmas level is prepared to accommodate the need to increase the ability and coverage of health services in an integrated and integrated manner with the problems that exist in the work environment of the puskesmas. Given the duties and functions of the puskesmas, namely implementing health policies to 
achieve health development goals in their working areas in supporting healthy sub-districts (Permenkes No. 75, 2014).

The guidelines for implementing the planning at the puskesmas level emphasize that in the process of implementing the planning at the puskesmas level, there are 4 (four) stages carried out, namely the preparation stage, the situation analysis stage, the preparation stage for the Proposed Activity Plan, and the last stage is the Activity Implementation Plan. (Permenkes No.44, 2016).

\section{Theoretical Review}

\section{Basic Planning}

Planning is a process of anticipating future events and determining strategies (means, adaptive actions) to achieve organizational goals in the future (The process of anticipating future events and determining strategically to achieve organizational objectives in the future (Supriyanto, 2007).

Planning is the first step taken in an effort to achieve goals, meaning that planning is an effort to concretize the steps that must be taken where the basics have been laid in the organization's strategy. Planning that is prepared through proper identification of problems based on accurate data, and obtained in the right way and at the right time, will be able to direct the health efforts carried out by the Health Center in achieving its goals and objectives. In an effort to cover the widest possible target community that must be served, and given the limited availability of resources, health services must be implemented in an integrated manner, both across programs and across sectors. The head of the Puskesmas (Community Health Center) must be able to build cooperation and coordinate programs internally at the Puskesmas and externally with cross-sector partners. Coordination with cross-sector is very necessary, because the causes and background of certain health problems may only be solved by cross-sectoral partners.

The Puskesmas planning process will follow the regional development planning cycle, starting from the village/Sub-district level, then compiled at the sub-district level and then proposed to the district/city health office. The planning of the Puskesmas that is needed is integrated with cross-sectoral sub-districts, which will be proposed through the sub-district to the district/city local government (Ministry of Health, 2016).

\section{Scope of Health Planning}

Health management is one part of 3 parts of health development, namely implementation, coaching/management and development of basic health efforts, namely; (1) Planning; (2) Execution; (3) Control of supervision and assessment of Health Efforts. Health planning focuses on efforts to improve the performance of the health system. Planning is the first function in the management function, which precedes the functions of organizing, manpower, leadership and control.

Planning is intended to help achieve organizational goals. By assuming certain future conditions and analyzing the consequences of each action uncertainty can be reduced and future successes have a greater probability (Reinke, 2018). The benefits of an organizational plan are; (1) Help managers to see the future; (2) Better coordination, coordination can occur between parts of the organization and between current and future satisfaction; (3) Emphasis on organizational goals. With planning organizational goals can be focused because organizational goals are the starting point for planning, managers will always be reminded of these goals (Wijono, 2018). 


\section{Integrated Health Planning and Budgeting}

Health planning is a dynamic and continuous process, including the process of formulating plans and the process of implementing the plans that have been determined. There are several systematic planning steps. Systematic planning is structured as a separate process, or planning as part of the management function. The steps or procedures in planning follow a systematic flow, meaning that they must follow a certain sequence. (Supriyanto, 2007). The success of a plan, apart from administrative and technical factors, is also often determined by the political will of policy actors. Each planning stage requires its own planning techniques and tools.

\section{Factors Affecting the Success of the Planning Process}

The success of planning mainly depends on knowledge, attitudes and motivation (Mills, et.al, 1991). The most important factor in planning is the integration between management elements in the form of human and non-human resources or internal factors.

Humans are the most important factor in management that can determine success or failure in dealing with the goals and objectives set. Internal factors in an organization cannot be separated from environmental factors or external factors must be considered and calculated carefully, because environmental factors can support but can also hinder (Soedjadi, 1995).

The education factor obtained, the development of existing science and technology, applicable laws and policies, the physical location where he is located and others, will affect attitudes and behavior and this behavior can be attached to the individual or organization, and behavior is only inherent in humans as individuals (Thoha, 2007).

Another factor that is no less important that affects a person's attitude is motivation. With motivation, an individual can effectively do his job. This is closely related to job satisfaction. According to Gerungan, motivation is something that creates enthusiasm or work motivation (Gerungan, 1982: 23). The greater the work motivation will increase work performance. Thus it can be said that work motivation is a very important factor in achieving organizational goals (Sinaga, 2018).

\section{Planning Coordination}

Planning coordination is important in the planning process. Planning will be efficient if there is coordination that is cored in the communication process between planning agencies and interested actors both horizontally and vertically. These activities are carried out through a planning coordination forum with relevant agencies including the community. Coordination within the government bureaucracy is essentially an effort to integrate (integrate) various interrelated interests and activities in order to achieve common goals and objectives (LAN RI, 1996). In relation to development, coordination needs to be implemented from between parts of projects, programs, sectors, sub-sectors to inter-sectors. It is further explained that in order to strengthen coordination in the parts carried out are complex, multi-sectoral, multi-functional, then coordination can be in the form of Teams, Committees, Working Groups, or Task Forces.

\section{Health Center Level Planning (PTP)}

Health center level planning, known as micro planning, is one of the functions of Puskesmas management. Together with the mini-workshops and the stratification of the Puskesmas, the three are one unit as a tool to carry out the management function (Health, D. 2006).

The definition of Puskesmas planning is as an effort to detail the activities of health efforts in order to achieve the desired public health status in a certain period in the future, so that the planning of the Puskesmas level is a systematic process of activities to compile and prepare 
activities to be carried out by the Puskesmas. in the following year to increase the coverage and quality of health services to the community in an effort to overcome local health problems (Health, D. 2006).

\section{Conceptual Framework}

Based on the literature review, the conceptual framework for conducting this research is as follows:

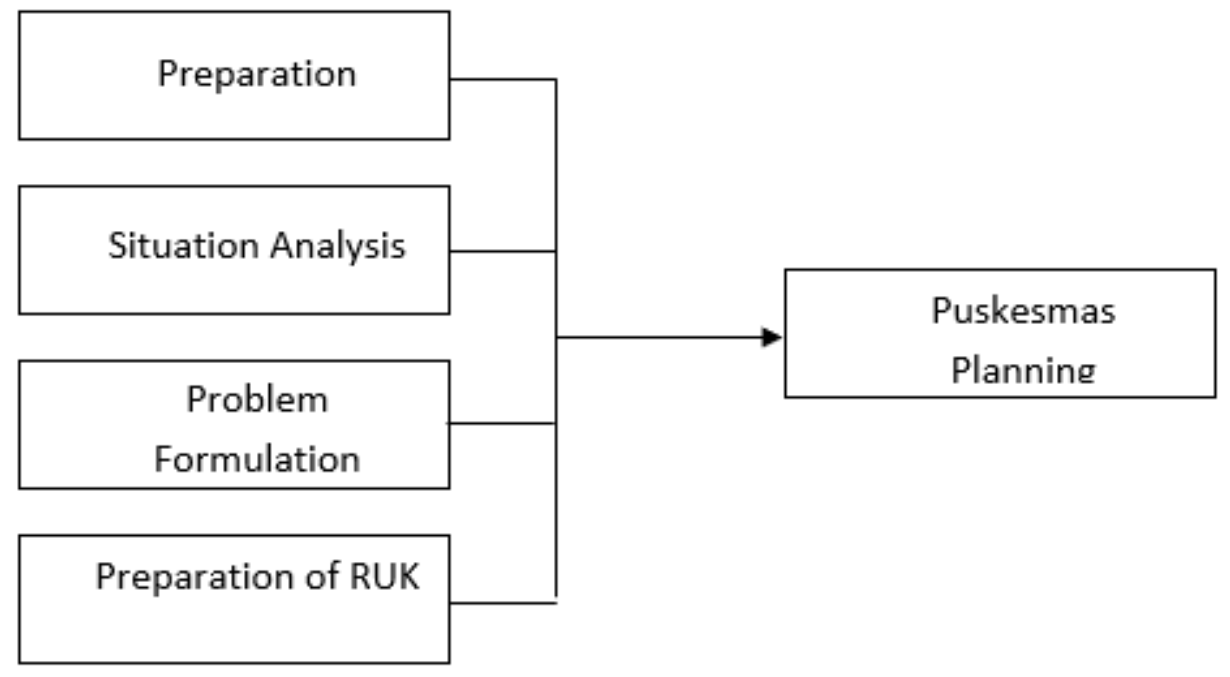

Figure 1. Conceptual Framework Scheme Developed from PTP Guidelines

\section{Methods}

\section{Types and Design of Research}

This type of research is qualitative, with the aim and revealaboutthe process of preparing planning at the puskesmas level in the Poso District Health Office by evaluating the planning of puskesmas level programs (Sugiyono, 2018).

\section{Analysis Unit and Research Subjects}

The analysis unit of this research was conducted on puskesmas in poso district health office environment, namely as many as 2 puskesmas.

\section{Results and Discussion}

\section{Overview of Research Sites}

Poso Regency consists of 19 districts, 28 sub-districts and 142 villages. In the northern hemisphere, the Poso Regency consists of the Districts of Poso Pesisir Utara, Poso Pesisir Selatan, Poso Pesisir, Poso Kota, Poso Kota Utara, Poso Kota Selatan and Lage, where part of the area borders the Gulf Coast of Tomini. In the eastern hemisphere is part of East Pamona bordering Morowali Regency and part of Lage bordering Tojo Una-Una Regency. In the western hemisphere, it consists of the Districts of North Lore, Central Lore and West Lore which borders the Donggala and Parigi Moutong Regencies. Meanwhile, South Pamona and South Lore Sub-districts are part of the border with South Sulawesi Province. Poso Regency has a population of 243,025 people (2017) with a population distribution of 34 people $/ \mathrm{km}^{2}$. (Poso District in Figures, 2018). 
Most of the health workers in Poso Regency (70.41\%) work in 23 Puskesmas while the others work in the Poso District Health Office and GFK (6.60\%), in Poso Hospital (21.12\%), Sinar Kasih Hospital Tentena (0.99\%), Poso District Blood Transfusion Unit (0.88\%) (Poso District in Figures, 2018).

\section{Research Results}

This research was conducted at the Sulewana Health Center, North Pamona District with Main Accreditation status and Taripa Health Center, East Pamona District with Middle Accreditation status and the Poso District Health Office. The variables studied were the preparation of puskesmas planning, situation analysis, problem formulation and preparation of the RUK.

The informants involved in this study were the Head of the Health Office in this case represented by the Head of Planning for the Health Service, the Head of the Sulewana Health Center in this case represented by the Head of Administration, the Head of the Taripa Health Center, and the Head of the Planning Team of the Sulewana and Taripa Health Centers. More details can be seen in the following table.

Table 1. Characteristics of Research Informants in Puskesmas Sulewana and Taripa Year 2020

\begin{tabular}{|c|c|c|c|c|}
\hline No & $\begin{array}{c}\text { Informant } \\
\text { Code }\end{array}$ & Gender & $\begin{array}{c}\text { Age } \\
\text { (Year) }\end{array}$ & Position \\
\hline 1 & TB & Man & 42 & $\begin{array}{c}\text { Head of Planning of Health Office } \\
\text { Of Poso District }\end{array}$ \\
\hline 2 & ZT & Man & 50 & Head of Taripa Health Center \\
\hline 3 & To & Woman & 35 & $\begin{array}{c}\text { Head of Planning Team of Taripa } \\
\text { Health Center }\end{array}$ \\
\hline 4 & CW & Man & 41 & $\begin{array}{c}\text { Head of Administration of } \\
\text { Puskesmas Sulewana }\end{array}$ \\
\hline 5 & NG & Man & 33 & $\begin{array}{c}\text { Head of Planning Team of } \\
\text { Puskesmas Sulewana }\end{array}$ \\
\hline
\end{tabular}

Source: Primary Data,2020

Based on the table, it is known that of the 5 informants at the Sulewana Health Center and Taripa Health Center, 4 informants were male and only 1 was female. There were 1 informants with age 50 years and $<50$ years as many as 4 people.

\section{Planning}

The Puskesmas planning process will follow the regional development planning cycle, starting from the village/kelurahan level, then compiled at the sub-district level and then proposed to the district/city health office. The planning of the Puskesmas is needed to be integrated with the sub-district cross-sector, which will be proposed through the sub-district to the district/city government. The Puskesmas will prepare a 5 (five) annual plan and the details of the annual plan based on the results of the previous year's evaluation and referring to health policies from the administrative levels above, both district/city, provincial, and central. For the purposes of preparing the Puskesmas planning, it is necessary to harmonize it with the Healthy Indonesia Program with a Family Approach and other national health programs. The planning stage begins with preparation (Permenkes, 2016).

Based on the results of interviews with informants at the Puskesmas, it was found that in the process of preparing for the planning at the puskesmas level, a planning team was formed by 
the head of the puskesmas as an initial stage which referred to the planning guidelines at the puskesmas level and the Minister of Health regarding puskesmas, then there were planning guidelines from the Health Department. However, the constraint is the lack of human resources in the field of management so that puskesmas still need experts in the management process so that planning can be carried out properly and provide maximum results.

In addition, the informants also know that the planning of the Puskesmas level is basically every organization must have a good plan to run the organization, and especially in the Puskesmas must have a plan which is part of the management process. Health center level planning is regulated in Permenkes No. 44 of 2016 and stated in the Public Health Center Management Manual. An analysis of the importance of planning at the Poso District Health Center from interviews showed that respondents knew that the implementation of puskesmas activities was largely determined by good planning.

According to Dhewi's research (2018) in Puskesmas in the city of Medan, the results of the study showed that all informants were aware of the planning of the puskesmas level in the city of Medan. Public health centers in the city of Medan have implemented or prepared a plan at the puskesmas level which is usually called the Plan Of Action (POA) for the puskesmas which is routinely made every year in accordance with the provisions of 4 stages in the planning guidelines (Dhewi, 2018).

The stages in the five-year puskesmas plan begin with preparing Puskesmas staff who are involved in the process of preparing the puskesmas five-year plan in order to obtain common views and knowledge to carry out the planning phase. This stage is carried out by the head of the puskesmas forming a puskesmas management team whose members consist of a regional development team, a family development team, a puskesmas accreditation team, and a puskesmas information system team. Furthermore, the head of the puskesmas explained the puskesmas management guidelines to the team so that they could understand these guidelines for the success of preparing the puskesmas five-year plan and the study team. This is in accordance with what was done at the Puskesmas in Poso Regency, but the obstacle for us in the team formation process was the lack of competent personnel in the field of management. For now, most of our puskesmas are nurses and midwives. We need a team that is quite competent in their respective fields to be able to support the implementation of an activity.

The Puskesmas level planning carried out in Poso Regency will directly support or boost the success of activities at the Puskesmas because in the puskesmas level planning there are plans that are prepared based on the problems that exist in the Puskesmas in carrying out service activities and it is certain if we make this plan based on the what is proposed is in accordance with the facts on the ground that what must be implemented is indeed automatic in the implementation of future activities, this will definitely succeed because it is carried out based on the existing problems.

\section{Situation Analysis}

The elements of the process are all the stages carried out in the planning of the Puskesmas level in the form of the preparation stage, the situation analysis stage, the stage of preparing the proposed activity plan and the stage of preparing the activity implementation plan. The situation analysis stage is intended to obtain information about the situation and identify health problems faced by the Puskesmas, in order to formulate service needs and fulfill rational community expectations in accordance with the conditions of the working area at the Puskesmas (Montain, 2019). 
The process of collecting performance data at the Puskesmas in Poso City is known that the data analysis process at the puskesmas is carried out in several stages, namely collecting data on the performance of the Puskesmas and describing the health status of the community. Then analyze the data and analyze the problem through the Self Insight Survey (SMD) which comes from the community's point of view. In the preparation of the five-year plan for the Puskesmas, data analysis was carried out by collecting data on the performance of the Puskesmas, a description of the health status of the community in the working area of the Puskesmas in the last 4 years. Meanwhile, the preparation of the One-Year Health Center Plan data is taken within one year. Based on the results of interviews with informants, it is known that the performance data of the Puskesmas is obtained from the performance data of SMEs which are summarized in the report on the achievement of MSS in the health sector and the performance data of the UKP which is summarized in the report on the condition of the number of disease cases. Puskesmas performance data are summarized in the Puskesmas information system, puskesmas profile data and patient satisfaction surveys. The process of analyzing data at the Puskesmas was carried out based on the description of the health status of the community that occurred previously.

The performance data of the Puskesmas is collected in 2 parts, namely the performance data of Community Health Efforts (UKM) through out-of-building programs which are summarized in the report on the achievements of the Minimum Service Standards (SPM) program in the health sector, and performance data in the building called Individual Health Efforts (UKP). which is summarized in the condition report on the number of cases of the disease. Health center performance data is needed in the preparation of the Five-Year Plan and One-Year Plan of the Puskesmas. Puskesmas performance data are the results of puskesmas activities recorded in the Puskesmas Information System (SIP), Puskesmas Profile data, as well as patient satisfaction survey data summarized in the Puskesmas Quality assessment data.

Based on the results of this research, it is known that the purpose of problem analysis is to understand the problem clearly and specifically, make it easier to determine problem priorities and make it easier to determine alternative problem solving. In addition, it is also important in the planning process because it can identify the actual health problems and how to provide health services to the community through the data and information collected. Because data and information are important, because it reduces uncertainty, with accurate data and information, uncertainty about a situation or problem can be reduced, making it easier to determine the priority scale with data and information will help in determining the priority scale of various existing problems, making it easier calculating resource requirements (resources) in the planning process, it is necessary to calculate resource requirements due to limited resources so that data and information will provide an overview of existing resources (Sudirman, 2019).

Self-Introspection Survey is an activity to identify the conditions and problems faced by the community, as well as the potential of the community to overcome these problems. The potentials include the availability of resources, as well as opportunities that can be mobilized. This is important to be identified by the community itself, so that the community can then be mobilized to participate actively in strengthening its improvement efforts, according to the limits of their authority (Hesti, 2018).

The stages start from collecting primary and secondary data, processing and presenting data on existing problems and potentials and building an agreement with the community and village/kelurahan heads, to jointly address health problems in the community. The SMD/CSS instruments are prepared by the Puskesmas according to the problems faced and the problems that the Puskesmas will address. The instruments compiled include a data collection format 
conducted by community representatives (community leaders, religious leaders, health cadres) who can identify public health problems and can provide information about: a. Possession of a Healthy Towards Card (KMS) for toddlers; b. Immunization status and nutritional status of children under five; c. Environmental conditions of the settlement/residential house; d. The condition of the house, the availability of clean water suitable for consumption, coverage of healthy latrines, Waste Water Disposal Facilities (SPAL) in the household; e. Caring for healthy and sick toddlers; f. Efforts to meet the health needs of toddlers (growth and development, balanced nutrition, immunization, Integrated Management of Toddler Sickness (MTBS), etc.); g. The role of the family in the utilization of health services in Community Based Health Efforts (UKBM); h. The role of the family in UKBM activities; and or i. Other questions that are considered necessary to find out the problems faced by the community (Aryanto, 2019).

\section{Problem Formulation}

The formulation of the problem is carried out as in the preparation of the Five-Year Plan of puskesmas. The problem is formulated based on the principle of $5 \mathrm{~W} 1 \mathrm{H}$ (What, Who, When, Where, Why and How/ What is the problem, who is affected by the problem, when the problem occurs, where the problem occurs, why and how the problem occurs) (Muninjaya, 2014). Based on the results of interviews with informants, it is known that in the process of identifying problems at the Puskesmas, it is done by making a list of problems which are then grouped by type of effort, targets, achievements and problems encountered in the field. The list of problems is presented in tabular form to be further sorted by priority of problems and become the main material for the preparation of the RKA.

Based on the results of interviews with informants, it is known that the priority of the problem is chosen based on the agreement of the team by considering the ability of the puskesmas in terms of infrastructure and human resources. The results of the study indicate that equipment such as computers and their devices are indispensable tools. In addition, the formats as guidelines sourced from the Poso City Health Office are also important in the implementation of planning at the Puskesmas level. Then in some puskesmas also use vehicles to collect the data needed in the preparation of the plan. In addition, based on the informant's statement, information was also obtained that so far there has been no special training at the district level for the preparation of this Puskesmas level planning. The information obtained from the district health office is that the resources available for conducting this management training are not yet qualified, and because the ministry always conducts this management training.

The results of the observation matrix used by the puskesmas are in accordance with the guidelines consisting of 12 column variables. The format for planning the puskesmas level itself has been regulated in the Minister of Health Regulation No. 44 of 2016. For the situation analysis phase, there is a cause-and-effect diagram of Ishikawa (Fishbone) and a Problem Tree. For the RUK and RPK themselves, a matrix is given which will later contain the activities of the Puskesmas. The matrix consists of 12 details columns as follows; Health Efforts, Activities, Objectives, Targets, Targets, Responsible Persons, Resource Needs, Partners, Implementation Time, Budget Requirements, Performance Indicators, and Funding Sources. The matrix can be developed according to local needs and policies but without reducing the existing column variables.

Based on the results of the explanation above, it can be seen that from the results of data analysis, the formulation of the problem was carried out. Problem is the gap between expectation and reality. This stage is carried out through: a. Problem Identification b. Setting the Order of Priority Problems c. Finding the Root Cause of the Problem d. Define Problem

Copyright ( 2021 , International Journal Papier Public Review, Under the license CC BY-SA 4.0 DOI: https://doi.org/10.47667/ijppr.v2i3.104 
Solving Methods Preparation of a five-year plan. Based on the agreement on how to solve the problem, a program of activities can be developed and the targets to be achieved are determined. Supervision and control for the achievement of the Five-Year Plan targets are carried out annually, and in the middle of the five-year period a Midterm evaluation is carried out, to adjust the final Five-Year Plan targets. This needs to be done to accommodate policy changes or new policies, the results of the analysis of program achievement trends, the possibility of additional resources and the possibility of new health problems. Details of the implementation of activities in achieving the priority targets that have been set in the five-year planning will be compiled in the annual planning of the Puskesmas (Passapari \& Sudirman, 2018).

\section{Preparation of RUK}

The stage of preparation of the Proposed Activity Plan is a stage that aims to maintain the activities that have been achieved and develop new activities (Artha, 2019). The purpose of the RUK is to identify what must be done, test and prove that the goals can be achieved, the ability to achieve the goals, the required resources can be obtained, all the necessary information can be obtained, there are several alternatives that must be considered and act as a good communication medium. can motivate interested parties in achieving goals (Hesti, 2018).

The preparation of the RUK at the Puskesmas which is carried out at the Poso City Health Center includes the upcoming annual activities, facilities/infrastructure, operations and programs resulting from the analysis of the problem. Resource needs are based on availability in the current year. Recapitulation of the proposed activity plan and required resources into the format of the Puskesmas RUK. Of course, the RUK of the Puskesmas still refers to various applicable government policies.

The results showed that there was an evaluation carried out by the Poso City Health Office, usually they did it through regular coordination meetings, at least once a month. The Health Office usually evaluates the achievements of programs or activities that have been implemented and those that have not been implemented. The informant's statement above also provides information that in the preparation of the proposed activity plan (RUK) the Puskesmas in Poso Scope always involves relevant cross-sectors and always receives assistance from the health office in every musrembang activity (deliberation on development plans). Given that the Puskesmas is the technical implementing unit of the district/city health office, the success of the implementation of the puskesmas to solve priority health problems cannot be separated from the responsibility of the district/city health office.

In preparing the RUK, please pay attention to several considerations such as paying attention to the ability of organizational resources or input components, such as: 1. Information 2 . Organization or mechanism 3. Technology or Method 4. Human Resources (HR), seeing that human resources those at the Puskesmas in Poso City are still not competent even though facilities and infrastructure are available. Therefore, training is needed to support the sustainability of the program (Supriyadi, 2019)

\section{Conclusion}

The results of the analysis of the planning process at the Puskesmas Level at the Poso District Health Office based on the preparation stage, a planning planning team was formed by the Head of the Puskesmas as an initial stage guided by the rules issued by the District Health Office. Poso and refer to Permenkes No. 44 of 2016 and stated in the puskesmas management manual. The results of the analysis of the planning process at the Puskesmas Level at the Poso District Health Office were based on the situation analysis phase. The data analysis process at

Copyright @ 2021, International Journal Papier Public Review, Under the license CC BY-SA 4.0 DOI: https://doi.org/10.47667/ijppr.v2i3.104 
the puskesmas was carried out in several stages, namely collecting data on the performance of the puskesmas and describing the health status of the community. Then analyze the data and analyze the problem through the Self Insight Survey (SMD) which comes from the community's point of view. The results of the analysis of the planning process at the Puskesmas Level at the Poso District Health Office based on the problem formulation stage, the method used in determining the priority of the problem by assessing the severity of a problem or commonly called the USG (Urgency Seriousness Growth) method while the method used in determining the root cause of the problem for health centers in the district. Poso is different. The method used is the Ishikawa diagram or commonly called the fishbone diagram and the problem tress method or problem tree. The results of the analysis of the planning process at the Puskesmas Level at the Poso District Health Office are based on the RUK (Proposed Activity Plan) preparation stage that is prepared at the puskesmas including upcoming annual activities, the required resources including facilities and infrastructure The RUK drawn up at the Puskesmas still refers to the applicable government policies.

\section{References}

Artha, B. D. (2019). Analisis Penyusunan Perencanaan Tingkat Puskesmas di Puskesmas Matiti Kecamatan Doloksanggul Kabupaten Humbang Hasundutan Tahun 2019. Repostitory USU, 1(9). http://repositori.usu.ac.id/handle/123456789/13297

Aryanto. (2019). Evaluasi Proses Perencanaan Tingkat Puskesmas di Lingkungan Dinas Kesehatan Kota Jayapura Provinsi Papua. Jurnal Administrasi Kesehatan, 1(5). http://www.kmpk.ugm.ac.id/id/index.php?subaction=showfull\&id=1258979215\&arc $\underline{\text { hive }=\& \text { start from }=\& u c a t=1 \& \text { ) }}$

Azrul, A. (1996). Pengantar Administrasi Kesehatan. Edisi Ketiga, Jakarta: Binarupa Aksara.

Deri, Z. (2019). Analisis Implementasi Penemuan Pasien TB Paru dalam Program Penanggulangan TB di Puskesmas Balai Selasa Kabupaten Pesisir Selatan Tahun 2018. Universitas Andalas.

Dhewi. (2018). Analisis perencanaan tingkat puskesmas di Kota Medan Tahun 2018. Jurnal Kesehatan Masyarakat Medan, 2(3).

DINKES, K. p. (2018). Modul pelatihan manajemen puskesmas dengan pendekatan keluarga.

Hesti. (2018). Perencanaan Tingkat Puskesmas Tahun 2018 Puskesmas Hajimena Hajimena Kecamatan Natar Lampung Selatan. Jurnal Kesehatan Masyarakat, 2 (2).

Montain, M. M. (2019). Analisis sistem perencanaan tingkat puskesmas di kabupaten Karawang. Universitas Indonesia Library, 1.

Muninjaya. (2014). Manajemen Kesehatan Edisi 2 (2nd ed.). EGC.

Passapari, \& Sudirman, N. (2018). Evaluasi Pelaksanaan Program Sistem Pencatatan Dan Pelaporan Terpadu Puskesmas (Sp2Tp) Di Puskesmas Kawua Kecamatan Poso Selatan Kabupaten Poso. Journal of Chemical Information and Modeling, 8(2). https://doi.org/10.1017/CBO9781107415324.004.

Reinke, W. A. (2018). Perencanaan Kesehatan Untuk Meningkatkan Efektifitas Manajemen. EGC

Sinaga, A. M. (2018). Kaitan Motivasi dengan Perilaku Organisasi.

Soedjadi, F. X. (1995). Analisis Manajemen Modern Jilid 1. Jakarta: Toko Gunung Agung. 
Sudirman. (2019). Perencanaan Dan Evaluasi Kesehatan.

Sugiyono. (2018). Metode Penelitian Kualitatif.

Supriyadi. (2019). Analisis Penerimaan Sistem Informasi Manajemen Puskesmas Elektronik (Simpustronik) dengan Pendekatan Technology Acceptance Model (TAM) pada Petugas BP (Balai Pengobatan Puskesmas di Kabupaten Situbondo. Jurnal Administrasi Kesehatan, 3(7).

Supriyanto, S., \& Damayanti, N. A. (2007). Perencanaan dan Evaluasi. In: Surabaya: Airlangga University Press.

Thoha, M. (2007). Perkembangan Kebijakan Pendidikan.

Wijono, S. (2018). Kepemimpinan Dalam Perspektif Organisasi 